THEORETICAL ASPECTS OF Population

Genetics 


\section{MONOGRAPHS IN POPULATION BIOLOGY}

\section{EDITED BY ROBERT H. MACARTHUR}

1. The Theory of Island Biogeography, by Robert H. MacArthur and Edward O. Wilson

2. Evolution in Changing Environments: Some Theoretical Explorations, by Richard Levins

3. The Adaptive Geomerry of Trees, by Henry S. Horn

4. Theoretical Aspects of Population Genetics, by Motoo Kimura and Tomoko Ohta 


\title{
THEORETICAL ASPECTS OF
}

\section{Population}

\section{Genetics}

\author{
MOTOO KIMURA AND \\ TOMOKO OHTA
}

\author{
PRINCETON, NEW JERSEY \\ PRINCETON UNIVERSITY PRESS \\ 1971
}


Copyright (C) 1971 by Princeton University Press ALL RIGHTS RESERVED

LC Card: 75-155963

ISBN: 0-691-08096-8 (hard cover edition)

ISBN: 0-691-08098-4 (paperback edition)

This book has been composed in Linofilm Baskerville Printed in the United States of America

by Quinn \& Boden Company, Inc., Rahway, N.J. 
TO JAMES F. CROW 
